\title{
EVALUATION OF TREATMENT BY VACUUM EVAPORATION AND THE LIQUOR BIOSORPTION PREHYDROLYZATE FROM BAGASSE CASHEW FOR PRODUCTION OF XYLITOL
}

F.C.S. LIMA*1, F.L.H. SILVA ${ }^{2}$, J.P. GOMES ${ }^{3}$, M.B. MUNIZ ${ }^{4}$, L.L. DE MEDEIROS ${ }^{5}$, C.G. SILVA $^{2}$

${ }^{1}$ Professor Doctor of Federal Institute of Education, Science and Technology - IFET/PE Campus Belo Jardim, Pernambuco, Brazil

${ }^{2}$ Department of Chemical Engineering, Center of Technology, Federal University of Paraiba, João Pessoa, Paraíba, Brazil

${ }^{3}$ Department of Agricultural Engineering, Center of Science and Technology, Federal University of Campina Grande, Campina Grande, Paraíba, Brazil

${ }^{4}$ Department of Process Engineering, Center of Science and Technology, Federal University of Campina Grande, Campina Grande, Paraíba, Brazil

${ }^{5}$ Graduate Program in Science and Food Technology, CT, UFPB, João Pessoa, Paraíba, Brazil

*Corresponding author: flavia.c.7@ hotmail.com

ABSTRACT - The cashew apple bagasse is a promising agroindustrial residue for biotechnological processes. Thus, by prehydrolysis of the hemicellulose fraction, are released both sugars compounds as inhibitors of fermentation. The aim of the present study was to evaluate the characterization liquor resulting from the acid prehydrolysis before and after the vacuum concentration and treatment with residual lignin. The bagasse was submitted acid prehydrolysis using $\mathrm{H}_{2} \mathrm{SO}_{4} 3 \%$ (weight/weight). The prehydrolyzate was concentrated and then treated with lignin residual, for improve the efficiency of the process for subsequent fermentation (production of xylitol). The liquor showed maximum concentrations of xylose, glucose and arabinose $(4.5 \mathrm{~g} / \mathrm{L}, 2.9 \mathrm{~g} / \mathrm{L}$ and $18.52 \mathrm{~g} / \mathrm{L})$ and minimum acetic acid, 5-HMF and furfural $(0.02 \mathrm{mg} / \mathrm{L}, 0.09 \mathrm{mg} / \mathrm{L}$ and $0.06 \mathrm{mg} / \mathrm{L})$ in the liquor treated. In the fermentation process, after 72 hours (preliminary study) was produced xylitol $2296.31 \mathrm{mg} / \mathrm{L}\left(\mathrm{Q}_{\mathrm{p}}=0.032 \mathrm{~g} / \mathrm{L} \mathrm{h}, \mathrm{Y}_{\mathrm{P} / \mathrm{S}}=89.06 \%\right)$.

\section{INTRODUCTION}

The lignocellulosic biomass, which is constituted of renewable organic compounds, presents with great potential of use as raw material in bioprocesses. These materials are the major constituents of vegetable biomass such as, for example, the residues of: rice straw, eucalyptus, sucarcane bagasse and corn cob, which are accumulated in the environment, causing problems of pollution and representing the loss of valuable resources (Lynd et al., 2005). 


\section{9 a 22 de outubro de 2014 \\ Florianópolis/SC}

The potential and the specific characteristics of the techniques for the use of these materials are related to their constitution. Its composition, in greater amount of sugars contained in cellulose fractions (glucose) and hemicellulose (xylose, arabinose, glucose, mannose and galactose) has been considered a promising alternative, attracting research that might use them as substrates in the production of xylitol and ethanol by fermentative pathway. Thus, are opening up opportunities for the development of an industry based on renewable raw materials (biorefineries). Besides the biofuels already known, a flow of innovations in development might be laying the foundation of an integrated industry of biomass exploration (Coutinho and Bontempo, 2010).

According to Pinho (2011), among the different biomasses that compose the lignocellulosic materials, bagasse from the cashew stalk stands out for being a byproduct of the Brazilian industry, with an estimated production of around 2 million tonnes/year and total use of only $20 \%$, with a waste of $80 \%$. Thereby making them, a promising source for bioconversion since it constitutes in abundant residue, renewable and low cost. In this way, the bagasse from the cashew stalk is an abundant agroindustrial residue, which presents in its composition, on average, $24.6 \%$ of cellulose, $15.1 \%$ hemicellulose and $24.6 \%$ lignin (Silva Neto et al., 2011).

In order that the lignocellulosic residues can be bioconverted, it is necessary the use of pretreatment that release the fermentable sugars existing in the composition of these materials (Lima et al., 2011). This procedure consists in using dilute acids so that occur the partial hydrolysis of the hemicellulose fraction most susceptible to the acid treatment (Aguilar et al., 2002). Also called prehydrolysis it is a process that employs less severe conditions, reaching high yields of conversion of xylans to xylose, besides presenting advantages for being less corrosive, toxic and dangerous compared to the use of concentrated acid (Sun and Cheng, 2002). The liquor obtained by this reaction contains constituent sugars from hemicellulose (xylose, glucose, arabinose, etc.), as also it is common to occur the formation of toxic compounds to the fermentation process (acetic acid, HMF and furfural). In this manner, it is necessary a suitable treatment to minimize these effects, in the liquor resulting from the prehydrolysis, which will be the raw material in the fermentation process (production of xylitol). The aims of this study were to evaluate the characterization (composition of formed sugars and inhibitors) of the liquor resulting from the acid prehydrolysis before and after concentration by evaporation and the treatment by adsorption with residual lignin.

\section{METHOD AND MATERIALS}

This work was developed in the Laboratory of Biochemical Engineering (LBE) and Laboratory of Porous Media and Particulate Systems (LPMPS) from the Academic Unit of Chemical Engineering in the Center of Science and Technology at the Federal University of Campina Grande - PB. It was used the cashew bagasse in natura, acquired from the juice production industry, FRUTNAT located in city of Campina Grande, Paraíba.

The bagasse was washed in running water until ${ }^{0}$ Brix near 0 . After washing, the bagasse was taken on trays to dry in oven with air circulation at temperature of $55^{\circ} \mathrm{C}$ for 48 hours. Shortly 


\section{9 a 22 de outubro de 2014 \\ Florianópolis/SC}

after it was milled in cutting mills (of the Tecnal brand) to reduce the size and sieved in a 48 mesh sieve and stored in polypropylene bags for later use

The yeast used in the research was Candida guilliermondii CCT 3544 (xylitol production) obtained at the Foundation André Tosselo - FAT Tropical Culture Collection.

\subsection{Acid prehydrolysis of cashew apple bagasse}

For the pretreatment, it was used the cashew residue on dry basis, which was treated with a dilute acid solution (sulfuric acid 95\% purity of the VETEC/PA brand). The liquor from the prehydrolysis was obtained at $105^{\circ} \mathrm{C}$ for $1 \mathrm{~h}$ in a stainless steel pressure reactor with capacity of $700 \mathrm{ml}$, using a weight ratio of 1:6 (100 $\mathrm{g}$ of sample/600 $\mathrm{g} \mathrm{H}_{2} \mathrm{SO}_{4}$ at $\left.3 \% \mathrm{v} / \mathrm{v}\right)$.

\subsection{Prehydrolyzate Concentration}

The prehydrolyzed liquor was subjected to the process of concentration in a rotary evaporator (of the Quimis brand) connected to a vacuum pump. The working temperature of the rotary evaporator was $70 \pm 5^{\circ} \mathrm{C}$ in order to increase the content of sugars, especially xylose. The original prehydrolyzate was concentrated by reduction of 1/2.5 (FC 2.5) of its initial volume.

\subsection{Tratament of the prehydrolyzate}

Then the liquor obtained from the acid prehydrolysis was treated using the chemical detoxification. This procedure involved the elevation of the initial $\mathrm{pH}(0.98)$ to final $\mathrm{pH}$ of 5.0 with addition of $17.5 \% \mathrm{NaOH}$. The liquor was then submitted to the adsorption process using as adsorbent the residual lignin according to the methodology described by Pivetta, (2008). The operating conditions were: 1:100 weight ratio ( $1 \mathrm{~g}$ of sample/100g of the pre-hydrolyzed liquor), keeping the mixture under stirring in a SHAKE type incubator under the conditions: $150 \mathrm{rpm}$ at $30^{\circ} \mathrm{C}$ for 1 hour, and vacuum filtered to eliminate the precipitate.

\subsection{Microorganism and inoculum preparation}

Candida guilliermondii CCT 3544 cells were maintained in the laboratory (LBE) on the malt extract Agar medium in $4^{\circ} \mathrm{C}$. For the inoculum preparation, the cells were transferred under aseptic conditions, with the aid of a platinum handle, to test tubes containing about $5 \mathrm{ml}$ of sterilized distilled water. $1 \mathrm{~mL}$ of aliquots of this suspension were then transferred to $125 \mathrm{~mL}$ Erlenmeyer flasks, containing $50 \mathrm{ml}$ of the medium constituted of $30 \mathrm{~g} / \mathrm{L}$ of xylose, $0.1 \mathrm{~g} / \mathrm{L}$ of calcium chloride, $3 \mathrm{~g} / \mathrm{L}$ of ammonium sulfate and $20 \mathrm{~g} / \mathrm{L}$ of rice bran extract. Maintained in a rotary incubator at $200 \mathrm{rpm}$, at $28{ }^{\circ} \mathrm{C}$ for 24 hours. The cells were then separated by centrifugation at $2000 \mathrm{Xg}$ for 15 minutes and then resuspended in sterile distilled water. Suitable volumes of this suspension were used in the fermentation, so that the initial cell concentration was $3 \mathrm{~g} / \mathrm{L}$. 


\section{9 a 22 de outubro de 2014 \\ Florianópolis/SC}

\subsection{Medium and fermentation conditions}

The detoxified and prehydrolyzed liquors and were sterilized in autoclave $\left(111^{\circ} \mathrm{C}\right.$ for 15 minutes) and supplemented with calcium chloride $(0.5 \mathrm{~g} / \mathrm{L})$, ammonium sulfate $(1.0 \mathrm{~g} / \mathrm{L})$ and rice bran extract $(20.0 \mathrm{~g} / \mathrm{L})$. All the fermentations were carried in an orbital shaker at $200 \mathrm{rpm}, 28^{\circ} \mathrm{C}$ in $125 \mathrm{~mL}$ Erlenmeyer flasks containing $50 \mathrm{~mL}$ medium. The flasks were inoculated with an initial cell concentration of mass of $3.0 \mathrm{~g} / \mathrm{L}$. The medium $\mathrm{pH}$ was adjusted to 4.0 at the beginning of fermentation.

\subsection{Analytical methods}

The prehydrolyzed liquor without being concentrate (original), concentrated, treated and fermented was characterized regarding to the concentrations of sugars (glucose, xylose and arabinose), acetic acid, hydroxymethylfurfural, furfural and xylitol. By means of HPLC equipped with a pump ProStar Model 210 (Varian); Manual injector with 20 $\mu \mathrm{L}$ loop; Refractive index detector, ProStar model 356 (Varian) and UV/visible $284 \mathrm{~nm}$ (aldehydes); Hi-Plex H stainless steel analytical column $(300 \mathrm{~mm} \times 7.7 \mathrm{~mm}$, Varian). The conditions of the operations were as follows: Column temperature of the $40^{\circ} \mathrm{C}$; Mobile phase: MilliQ water with an outflow 0.6 $\mathrm{mL} / \mathrm{min}$; Analysis time: 15 and 60 minutes to sugar contents and aldehydes, respectively. Internal standard solutions of sugars: glucose, xylose, arabinose and sucrose (Sigma 99.99\% HPLC grade), HMF congeners (Aldrich 99.98\%) and furfural (Vetec $99.9 \mathrm{UV} / \mathrm{HPLC}$ ) were used in the quantification of the liquor components.

\subsection{Statistical analysis}

The ASSISTAT program was used (Silva and Azevedo, 2009), where was applied the Tukey's test, with $5 \%$ of probability, of sugars (xylose, arabinose and glucose) and fermentation inhibitors (acetic acid, HMF and furfural).

\section{RESULTS AND DISCUSSION}

The characterization results of the prehydrolyzed liquor, before and after concentration and treatment procedures, can be found in Table 1 .

It can be seen in Table 1, the acid prehydrolysis of the bagasse from the cashew stalk has made possible the obtainment of liquor with predominant values for pentoses: xylose $(1.43 \mathrm{~g} / \mathrm{L})$ and arabinose $(7.12 \mathrm{~g} / \mathrm{L})$ corresponding to $92.64 \%$ compared to glucose $(0.63 \mathrm{~g} / \mathrm{L})$. It should be noted that after the concentration the prehydrolyzate liquor occurred a significant increase in the content of these sugars, at around 2.5 times. Cunha (2006), Tamanini, also found similar values and Hauly (2004) and Sarrouh (2009) that verified the non-degradation of the sugars in the concentration step. According to these results, can be seen that the prehydrolysis process was able to liberate in the pre-treated liquor the sugars present in the hemicellulosic fraction of the 
bagasse from the cashew stalk, also forming toxic components resulting, in part from the degradation of glucose (HMF) and xylose (Furfural).

Table 1 - Components of the hemicellulosic prehydrolyzate of the bagasse from the original cashew apple, concentrated and treated.

\begin{tabular}{cccc}
\hline Concentration & \multicolumn{3}{c}{ Liquor prehydrolyzate } \\
\cline { 2 - 4 } & Original & Concentrated & Treated \\
\hline Xylose $(\mathrm{g} / \mathrm{L})$ & $1.43 \mathrm{c}$ & $3.97 \mathrm{~b}$ & $4.54 \mathrm{a}$ \\
Glucose $(\mathrm{g} / \mathrm{L})$ & $0.63 \mathrm{c}$ & $2.62 \mathrm{~b}$ & $2.90 \mathrm{a}$ \\
Arabinose $(\mathrm{g} / \mathrm{L})$ & $7.12 \mathrm{c}$ & $17.76 \mathrm{~b}$ & $18.52 \mathrm{a}$ \\
Acetic acid $(\mathrm{mg} / \mathrm{L})$ & $343.75 \mathrm{a}$ & $69.00 \mathrm{~b}$ & $19.00 \mathrm{c}$ \\
$5-H M F(\mathrm{mg} / \mathrm{L})$ & $0.02 \mathrm{c}$ & $0.22 \mathrm{a}$ & $0.09 \mathrm{~b}$ \\
Furfural $(\mathrm{mg} / \mathrm{L})$ & $0.09 \mathrm{a}$ & $0.05 \mathrm{a}$ & $0.06 \mathrm{a}$ \\
\hline
\end{tabular}

Means followed by the same letter in the row do not differ by Tukey test at $5 \%$ probability

It is also observed in Table 1 that the prehydrolyzed liquor presents several compounds considered toxic to yeasts, such as acetic acid $(343.75 \mathrm{mg} / \mathrm{L})$, furfural $(0.02 \mathrm{mg} / \mathrm{L})$ and hydroxymethylfurfural $(0.09 \mathrm{mg} / \mathrm{L})$, and being these generated from the degradation of pentoses and hexoses, as analyzed and reported by Silva et al. (2007), Carvalho et al. (2005). Duarte et al. (2005) reported that the presence of concentrations above $3 \mathrm{~g} / \mathrm{L}$ of acetic acid, $1.5 \mathrm{~g} / \mathrm{L}$ of HMF and $1 \mathrm{~g} / \mathrm{L}$ furfural, has toxic effects, being sufficient to inhibit the action of microorganisms in the fermentation process. Depending on the concentrations of toxic (HMF, furfural and acetic acid) there may be the need for some kind of treatment for detoxification, because, even presenting in the pre-hydrolyzed liquor concentrations under the minimum concentration that is toxic can inhibit the fermentation process, due to the synergy of the inhibitory compounds. The toxic effect occasioned by the furanic compounds appears to be associated with the fact that, by being aldehydes, chemically reactive, can react with certain biological molecules such as lipids, proteins and nucleic acids or cause damage to the cell membrane (Palmqvist et al. 2000; Duarte et al. 2005; Rocha et al. 2011).

It also appears that in Table 1, after the concentration step the contents of sugar increasesed proportionally to the concentration factor employed (2.5 times). This is probably due to the nondegradation of sugars during the process. However, among the toxic compounds, despite having their values increased $(0.02$ to $0.22 \mathrm{mg} / \mathrm{L})$ for $\mathrm{HMF}$, this trend was not observed in the same way for acetic acid $(345.75-69.00 \mathrm{mg} / \mathrm{L})$ and furfural $(0.09-0.05 \mathrm{mg} / \mathrm{L})$ which decreased. Similar behavior was reported by Mussato et al. (2004) that found equal values to (1.24 g/L) acetic acid, $(0.11 \mathrm{~g} / \mathrm{L})$ for HMF and furfural (nd) under the same conditions of this work (2.5 times). This probably occurred due to the conditions employed during concentration, provoking the partial volatilization of these compounds.

For the concentrations of acetic acid (19.00 mg/L), HMF (0.09 mg/L) and furfural (0.06 $\mathrm{mg} / \mathrm{L})$ after detoxification process, it is observed that the behavior was coherent to the reported by Silva and Felipe (2006), Carvalho et al. (2005) and Tamanini and Hauly (2004). It has been 
found that the process of detoxification promoted partial removal of acetic acid, HMF and furfural, respectively. It's noted that didn't occur losses in the content of sugars (xylose, glucose and arabinose) in the prehydrolyzed liquor after detoxification treatment, fact that was desired, since the increase in the initial concentration of xylose favors the production of xylitol.

It is observed in Figure 1, variations on the concentrations of xylose, xylitol over time in the fermentations.

As shown in Figure 1, throughout the fermentation, insofar as the xylose is consumed, there is a linear decrease of its concentration and an increase of xylitol. In this step were analyzed the responses of xylitol yield factor ( $\mathrm{Y}_{\mathrm{P} / \mathrm{S}}=$ gram of xylitol formed per gram of xylose consumed) and volumetric productivity ( $\mathrm{Qp}=$ gram of xylitol formed per liter of medium per hour) obtained at the end of fermentation (72 hours). In fact, the highest concentration of xylitol was 2296.31 $\mathrm{mg} / \mathrm{L}$ after 72 hours of fermentation, with $\mathrm{Qp}=0.032 \mathrm{~g} / \mathrm{L} \mathrm{h}$ and $\mathrm{Y}_{\mathrm{P} / \mathrm{S}}=89.06 \%$.

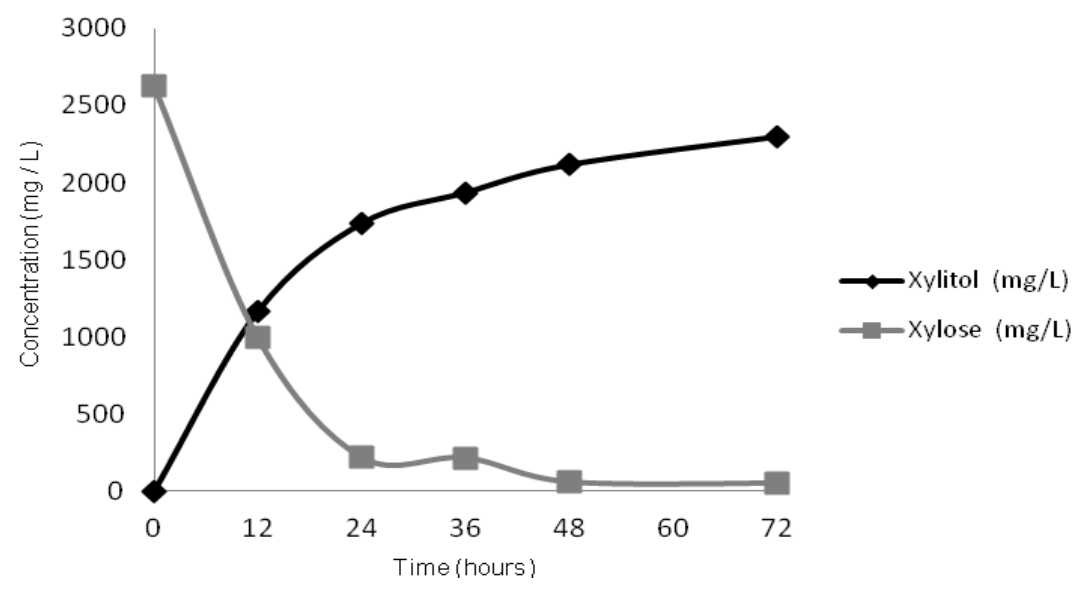

Figure 1 - Profile of consumption of xylose and xylitol production in function of the fermentation time.

Similar profile of xylose consumption and xylitol production is reported by other authors through the fermentation kinetic parameters such as Pivetta et al. (2008) who observed in the hydrolyzate of the sugarcane bagasse the productivity values $(0.48 \mathrm{~g} / \mathrm{L} \mathrm{h})$ and yield $(0.79 \mathrm{~g} / \mathrm{g})$ of xylitol. Now Ferreira et al. (2005) verified that after 72 hours of fermentation a xylitol production of $35.63 \mathrm{~g} / \mathrm{L}$, with a conversion of $63 \%$ of the consumed xylose to xylitol, accompanied by a volumetric productivity of $0.50 \mathrm{~g} / \mathrm{L} \mathrm{h}$ and bioconversion efficiency of $69 \%$ regarding to the theoretical value of yield in xylitol. Barbosa et al. (2008) when studying the ability of Candida guilliermondii to ferment hemicellulosic hydrolyzate of barley straw, have obtained an efficiency of $60.4 \%$ of bioconversion of xylose to xylitol with $0.48 \mathrm{~g} / \mathrm{L} . \mathrm{h}$ and $0.55 \mathrm{~g} / \mathrm{g}$ for volumetric productivity and conversion factor with $48 \mathrm{~h}$ of fermentation. However, Gimenes et al. (2003) verified when studying the influence of the initial xylose concentration on xylitol production by 
Candida guilliermondii that the maximum accumulation of xylitol coincided with the exhaustion of xylose, reaching the best factors in xylitol yield (YP/S) and volumetric productivities (QP) with average values of $0.794 \mathrm{~g} / \mathrm{g}$ and $1.1 \mathrm{~g} / \mathrm{L} \mathrm{h}$, respectively.

\section{CONCLUSION}

The results of this study allow to conclude that the prehydrolyzed liquor from the cashew apple bagasse presents great potential for use as fermentation medium, this is due the conditions employed in the acid prehydrolysis, but also, the concentration procedures and treatment, providing high concentrations of sugars and a bigger removal of inhibitors, becoming favorable the xylitol production.

\section{REFERENCES}

AGUILAR R., RAMÍREZ J.A., GARROTE G., VÁZQUEZ M. Kinetic study of the acid hydrolysis of sugar cane bagasse. J. Food Eng., v.5, p.309-318, 2002.

BARBOSA C.R., PRATA A.M.R., SILVA J.B.A. Fermentação do Hidrolisado Hemicelulósico da Palha de Cevada e Determinação das Condições de Hidrólise da Fração Celulósica do Resíduo In: XVII Congresso Brasileiro de Engenharia Química (COBEQ), 2008, Recife/PE. Anais do XVII COBEQ, v.3, p.1-7, 2008.

CARVALHO R.J., MARTON J.M., FELIPE M.G.A. Avaliação do sistema combinado de tratamento do hidrolisado hemicelulósico de bagaço de cana-de-açúcar com carvão ativo e resinas de troca iônica para sua utilização como meio de fermentação. Rev. Analit., v.18, p.48 $55,2005$.

COUTINHO P.L.A., BOMTEMPO J.V. Uso de roadmaps tecnológicos para favorecer o ambiente de inovaçao: uma proposta em matérias primas renováveis. In: SIMPO I, 2010, Anais, p.2-16, 2010.

DUARTE L.C., CARVALHEIRO F., NEVES I., GÍRIO F.M. Effects of Aliphatic Acids, Furfural, and Phenolic Compounds on Debaryomyces hansenii CCMI 941, Appl. Biochem. Biotechnol. J., v.121-124, p.413 - 426, 2005.

FERREIRA S.T.S., LOPES K.F., CUNHA, M.A.A., SILVA, S.S. Imobilização de Candida guilliermondii em pva-criogel para bioprodução de xilitol a partir de bagaço de cana-de-açúcar. In: VI congresso brasileiro de engenharia química em iniciação científica, 2005, Anais do VI COBEQ-IC, v..3, p.1-6, 2005.

GIMENES M.A.P., LIMA C.M., PEREIRA JR. N. Influência da Concentração Inicial de Xilose na Demanda Potencial de Oxigênio e nas Variáveis de Resposta na Produção de Xilitol por Candida guilliermondii In: Simpósio Nacional de Fermentações, 2003, Florianópolis. Anais do XIV SINAFERM - Simpósio Nacional de Fermentações, p. 1-6, 2003. 


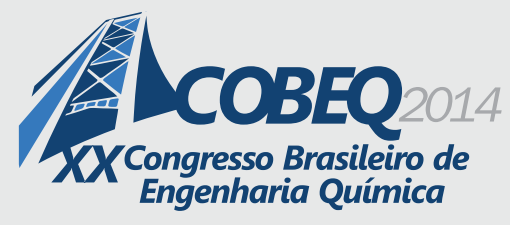

\section{9 a 22 de outubro de 2014 \\ Florianópolis/SC}

LIMA F.C.S., SILVA F.L.H., LIMA E.E., SILVA NETO J.M., SILVA A.S. Estudo de adsorção dos inibidores do licor pré-hidrolisado do bagaço do pedúnculo de caju. In: XVIII Simpósio Nacional de Bioprocessos - Anais do XVIII SINAFERM, v. CD, p.1-6, 2011.

LYND L.R., ZYL W.H.V., MCBRIDE J.E., Laser M. Consolidated bioprocessing of cellulosic biomass: Curr. Opin. Biotechnol. v.16, p.577-583, 2005.

MUSSATTO S.I., VAZ A.C.S., ROBERTO I.C. Efeito da concentração inicial de xilose na produção de xilitol a partir de hidrolisado de bagaço de malte. In: VIII Encontro LatinoAmericano de Iniciação Científica, São José dos Campos / SP. Anais / CD-ROM de trabalhos completos, p.527-530, 2004.

PALMQVIST E., HAHN-HÄGERDAL B. Fermentation of lignocellulosics hydrolysates: Inhibition and detoxification. Biores.Technol, v.74, p.17-24, 2000.

PINHO L.X., AFONSO M.R.A., CARIOCA J.O.B., COSTA J.M.C., RYBKA A.C.P. Desidratação e aproveitamento de resíduo de pedúnculo de caju como adição de fibra na elaboração de hambúrguer, Rev. Braz. J. F. and Nutri. Araraquara, v.22, p.571-576, 2011.

PIVETTA L.R., ARRUDA P.V., FELIPE M.G.A. Comparação de metodologias de destoxificação do hidrolisado de bagaço de cana para a produção de xilitol por via fermentativa, VIII Encontro Latino Americano de Pós-Graduação - Anais - Universidade do Vale do Paraíba, 2008.

ROCHA V.M.P., RODRIGUES H.T.S., MELO M.M.V., GONÇALVES L.R.B., MACEDO G.R. Cashew Apple Bagasse as a Source of Sugars for Ethanol Production by Klu-yveromyces Marxianus CE025, J. Ind. Microbiol. Biotechnol., v.38, p.1099-1107, 2011. doi:10.1007/s10295010-0889-0

SARROUH B.F., SANTOS, D.T., CONVERTI, A., SILVA, S.S. Technical-Economical Evaluation of Sugarcane Bagasse Hydrolysis for Bioethanol Production. Chem. Eng. Technol., New Jersey, v.30, p.1-7, 2007.

SILVA NETO J.M., SILVA F.L.H., LIMA E.E., TORRES NETO A.B., LIMA F.C.S. Análise do pré-tratamento ácido do bagaço do pedúnculo do caju IX Congresso Brasileiro de Engenharia Química - Iniciação Científica - Maringá, Paraná, Anais do IX COBEQ-IC p.1-6, 2011.

SILVA D.D.V., MANCILHA I.M., SILVA S.S., FELIPE M.G.A. Improvement of Biotechnological Xylitol Production by Glucose During Cultive of Candida guilliermondii in Sugarcane Bagasse Hydrolysate. Braz. Arch. Biol. Technol., v.50, p.207-215, 2007.

SILVA D.D.V., FELIPE M.G.A. Effect of glucose: xylose ratio on xylose reductase and xylitol dehydrogenase activities from Candida guilliermondii in sugarcane bagasse hydrolysate. $J$. Chem. Technol. Biotechnol., v.81, p.1294-1300, 2006.

SUN Y., CHENG J. Hydrolysis of lignocellulosic materials for ethanol production: a review Bioresour. Technol., v.83, p.1-11, 2002.

TAMANINI C., HAULY M.C.O. Resíduos agroindustriais para produção biotecnológica de xilitol. Semina: Ciênc. Agra..25, p.315-330, 2004. 